\title{
A New Method of Extracting Whole Cell Proteins from Soil Microorganisms Using Pre-treatment of Ammonium Hydroxide
}

\author{
Han-Chul Kang* · Jong-Bum Kim $\cdot$ Kyung Hee Roh $\cdot$ Sang-Hong Yoon
}

Received: 22 October 2012 / Accepted: 30 December 2012 / Published Online: 30 September 2013

(C) The Korean Society for Applied Biological Chemistry 2013

\begin{abstract}
Efficient extraction of total proteins from soil microorganisms is tedious because of small quantity. In this regard, an improved method for extraction of whole cell proteins is developed from soil microorganisms, Saccharomyces cerevisiae and Pichia pastoris. of which the cell wall are very strong. Pretreatment with $\mathrm{NH} 4 \mathrm{OH}$ prior to the final extraction using $\mathrm{NaOH} /$ SDS was tried under the basis that ammonium ion was possible to enhance the permeability and/or to weaken the yeast cell walls. The pre-treatment of yeast cells with $\mathrm{NH} 4 \mathrm{OH}$ drastically enhanced the protein extraction when it was compared with control (without $\mathrm{NH} 4 \mathrm{OH}$ pre-treatment). At the pre-treatment of $0.04 \mathrm{~N} \mathrm{NH} 4 \mathrm{OH}$ at $\mathrm{pH} 9.0$, about 3 fold of proteins was obtained from $p$. pastoris. Ammonium hydroxide appears to penetrate into the yeast cell walls more readily at basic $\mathrm{pH}$. The effect of $\mathrm{NH} 4 \mathrm{OH}$ pretreatment was $\mathrm{pH}$ dependent. The methods developed in this experiment might be applicable for an effective extraction of yeast proteins for the purpose of biochemical studies, especially proteomic analysis.
\end{abstract}

Keywords ammonium hydroxide $\cdot$ protein extraction $\cdot$ yeast

\section{Introduction}

The yeast strains including $S$. cerevisiae are frequently used as a model eukaryotic organism for studying wide range of biochemical and molecular aspects such as cell cycle regulation, DNA repair, signal transduction, and stress response etc. In general, the cell wall of $S$. cerevisiae consists of two layers. Inner layer includes $\beta$ 1,3-glucan and chitin, which form skeletal polysaccharides and

H. -C. Kang · J. -B. Kim · K. H. Roh · S-H Yoon

Department of metabolic engineering, National Academy of Agricultural Science, Rural Development Administration, Suwon 441-707, Republic of Korea

*Corresponding author (H. -C. Kang: hckang09@korea.kr) are responsible for mechanical strength as well as porous network (for review; Klis et al., 2006). Outer layer is also a complex structure consisting mainly of proteins, mannan oligosaccharides, and $\beta-1,6$-glucan. Most of the proteins are associated with the mannan oligosaccharides, hence referred to as mannoprotein complexes (Huang et al., 2005). The two polysaccharides, Dmannan and $\beta$-D-glucan in $S$. cerevisiae, are major polysaccharides in yeast cells (Klis et al., 2006). Inner and outer layers architected with these polysaccharides and protein complexes contribute to the strength of the cell walls, showing chemical and physical stability.

For the purpose of various research works, extraction of whole cell proteins is often required and followed by proteomic analysis, which is one of the most commonly used methods. Currently, the widely used methods for protein extraction from microbe, plant, or animal cells include mechanical breakage and chemical extraction. Protein extraction from $S$. cerevisiae was developed by using glass beads (Conzelmann et al., 1988). Recently, a method of extraction from $S$. cerevisiae was tried by cryogenic grinding (Singh et al., 2009). The preparation of yeast proteins has been often tried with other mechanical methods, too. But the mechanical methods can be accompanied with some disadvantages such as tedious work and irregular extent of total proteins released. This problem can provoke a confusion, especially, when a level of protein expression should be analyzed or compared with each other. Other method for protein extraction from $S$. cerevisiae was developed, which included a method of boiling in optimized sodium dodecyl sulfate polyacrylamide gel electrophoresis (SDS-PAGE) sample buffer (Horwath and Riezman, 1995). The authors noted that the method was rapid, however protein content was not sufficient with cells grown up to stationary phase on minimal media. Especially, yield of protein with higher molecular weight was reduced. Combined method of using laminarinase and sodium dodecyl sulfate polyacrylamide gel electrophoresis (SDS) was developed from $S$. cerevisiae (Mrsa and Tanner, 1999). In addition to Saccharomyces, development of protein extraction from Pichia has been steadily studied, which was developed with SDS acetone, or other 
chemicals such as urea (Kwasiborski et al., 2012).

On the other hand, $\mathrm{NaOH}$ solution has been often used in order to weaken the cell wall of plant during various processes of biotechnological purpose. Besides $\mathrm{NaOH}$, other alkaline solution, $\mathrm{NH} 4 \mathrm{OH}$ was tried in order to weaken the soybean fiber and thus enzymatic saccharification increased markedly (Karki et al., 2011). In this experiment, saccharification was more produced from the treatment with $\mathrm{NH} 4 \mathrm{OH}$ than that with $\mathrm{NaOH}$. There was another observation that ammonium ion can penetrate the crystalline structure of sugar cane and cause swelling the plant cell (Aita et al., 2010). Treatment of ammonium ion removed a large proportion of the lignin of sugarcane bagasse without influencing the structural integrity of the plant cell (Beukes et al., 2011), resulting in a drastic increase in enzymatic product. On the other hand, ammonium ion was also used to isolate complex substances from other biomaterial source. The extracellular organic matters in sludge was effectively extracted along with the treatment of $\mathrm{NH} 4 \mathrm{OH}$ and brought about negligible shift in their fluorophore characteristics (Chen et al., 2003). In this experiment, $\mathrm{NH} 4 \mathrm{OH}$ was more effective to extract the extracellular polymeric substances than treatment with $\mathrm{NaOH}$, suggesting that $\mathrm{NH} 4 \mathrm{OH}$ can more efficiently weaken chemical interaction. Similar to these findings, Fujita et al., (2007) showed that ammonium ion can reduce hydrophobic interactions under the basis of molecular dynamics simulations, which calculates the pair potential of mean force as a quantitative measure of hydrophobic interactions.

On the analogy of these findings, it can be expected that $\mathrm{NH} 4 \mathrm{OH}$ can efficiently weaken the microbial cell wall and/or other hydrophobic interactions in the cell. The structure of yeast cell wall is considered to be hard and, thus, more severe conditions might be necessary in order to disrupt the cell for an effective extraction of proteins. We describe an ameliorated method for protein extraction from yeast cells, which involves a pre-treatment with $\mathrm{NH} 4 \mathrm{OH}$.

\section{Materials and Methods}

Yeast strains and growth medium. The yeast strains used in this study were Scacharomyces cerevisiae (KACC 30008 and KACC 30044) and Pichia pastoris X-33. The strain KACC 30008 is a wild type, baker's yeast. Another Saccharomyces strain, KACC 30044, shows a characteristic of its genotype, his3 and ura3. These two strains were obtained from Korean Agricultural Culture Collection (KACC). Another yeast strain, P. pastoris X-33, was supplied from Invitrogen (USA, CA). Genotype of the Pichia strain is a wild type with phenotype Mut ${ }^{+}$.

All of these yeast cells were grown using $50 \mathrm{~mL}$ of liquid YPD medium ( $1 \%$ yeast extract, 2\% peptone, and 2\% glucose). Cultures were also maintained on solid YPD medium plate supplemented with $1.5 \%$ agar. For the purpose of protein extraction, the yeast cells were cultured up to stationary phase at $37^{\circ} \mathrm{C}$ with agitation of $200 \mathrm{rpm}$ in an orbital incubator. The yeast cells were harvested by centrifugation at $9000 \mathrm{~g}$ for $5 \mathrm{~min}$, then washed with ice-cold Tris-HCl buffer ( $\mathrm{pH} 7.0,0.1 \mathrm{M})$. At this stage, the growth of yeast cells was measured spectrophotometrically after replacement of suspension with the same volume of Tris- $\mathrm{HCl}$ (pH 9.0, 0.1 m). Each OD600 nm measured with 1.0 $\mathrm{cm}$ width of cuvette was about 1.0 1.5. Wet weights of yeast cells were about $8-10 \mathrm{mg} / \mathrm{mL}$ (culture solution) at the each stationary phase. The glucan structures in yeast cells, which contribute considerably to the strength of cell wall, are much produced and form a microfibrillar like network during stationary growth phase (Klis et al., 2006). Thus, for the purpose of using robust cells, we used yeast cells which were cultured up to stationary phase throughout the experiments.

Pre-treatment of yeast cells with ammonium or sodium hydroxide solution. Yeast pellets were resuspended in a sample buffer consisted of Tris- $\mathrm{HCl}(0.1 \mathrm{M}, \mathrm{pH} 7.0), 1 \mathrm{mM}$ phenylmethylsulfonylfluoride (PMSF) and $0.2 \mathrm{mM}$ ethylene diamine tetra-acetic acid (EDTA). Each suspension (containing over $40 \mathrm{mg}$ of yeast cells by wet weight) was equally redistributed into microtube. For the pre-treatment of yeast cells, $\mathrm{NH} 4 \mathrm{OH}$ or $\mathrm{NaOH}$ was added up to $0.15 \mathrm{~N}$ (final concentration) to the cell suspension. The cell suspensions were incubated at room temperature for $4 \mathrm{~h}$. After the incubation, the cell suspensions were added with $0.1 \mathrm{~N}$ $\mathrm{NaOH}$ and $1 \%$ SDS (final concentration). For the final step of protein extraction, the suspension mixtures $(1 \mathrm{~mL}$ of final total volume) were heated at $40^{\circ} \mathrm{C}$ for $10 \mathrm{~min}$, then centrifuged at $12000 \mathrm{rpm}$. The supernatant obtained was used for the analysis of protein extraction.

Pre-treatment of ammonium hydroxide at different $\mathbf{p H}$. Pretreatment of $\mathrm{NH} 4 \mathrm{OH}$ solution was performed at different $\mathrm{pH}$ values as follows: $\mathrm{pH} 5.0$, sodium acetate $(0.1 \mathrm{M}) ; \mathrm{pH} 6.0$, sodium phosphate $(0.1 \mathrm{M})$; $\mathrm{pH} 7.0,8.0$, and 9.0 , Tris/ $\mathrm{HCl}(0.1 \mathrm{M})$. The yeast cells grown up to stationary phase were distributed into each eppendorf tube. The cells were washed with Tris/ $\mathrm{HCl}(\mathrm{pH} 7.0,0.1$ $\mathrm{M})$. The resulting pellets were resuspended with each buffer as described above, thus resulting in $\mathrm{pH}$ values from 5.0 to 9.0 at this experimental step. Then $0.05 \mathrm{~N} \mathrm{NH} 4 \mathrm{OH}$ (final concentration) was introduced into each microtube, then incubated for $4 \mathrm{~h}$ at room temperature. The yeast cells were centrifuged and supernatants discarded. The resulting pellets were resuspended with Tris/ $\mathrm{HCl}$ pH $9.0(0.1 \mathrm{M})$ supplemented with $1 \mathrm{mM}$ PMSF and $0.2 \mathrm{mM}$ EDTA. The proteins were finally extracted as described using 0.1 $\mathrm{N} \mathrm{NaOH}$ and $1.0 \%$ SDS.

Other analytical methods. Determination of protein concentration was based on the method of Bradford (1976). Since final step of protein extraction from the yeast cells were performed at alkaline condition throughout the experiments, final solution of protein extracted is under alkaline condition. However, proteins more bind to the Coomassie blue dye at acidic $\mathrm{pH}$ condition rather than alkaline $\mathrm{pH}$ condition. Therefore, for better analysis, protein extract was supplemented with an acidic buffer, sodium acetate buffer (0.1 M, pH 5.0) before measurement of protein concentration. Bradford solution was added as a freshly prepared mixture just before measurement. Incubation was performed for $10 \mathrm{~min}$ with slow agitation in order to minimize a formation of dye-dye 
complex, which may hinder the protein quantification. The protein concentrations, which were calculated from mean values of three test samples, were represented as a concentration equivalent to bovine serum albumin as a standard protein.

The efficiencies of protein extraction were also analyzed by protein electrophoresis. SDS-PAGE was performed according to the routine method (Laemmli, 1970) using 5\% stacking gel and $12.5 \%$ resolving gel, followed by staining of the proteins with Coomassie Brilliant Blue R-250.

\section{Results}

Preliminary experiment of protein extraction using a combination of SDS and $\mathrm{NaOH}$. In advance of trying a pretreatment with $\mathrm{NH} 4 \mathrm{OH}$, we examined whether protein extraction with SDS alone can be applicable to the yeast cells. For this experiment, the yeast cells, S. cerevisiae (KACC 30008 and 30044) and $P$. pastoris, were grown up to stationary phase. The subsequent pellets were suspended with Tris- $\mathrm{HCl}(\mathrm{pH}$ 9.0, 0.1 M) supplemented with $0.2 \mathrm{mM}$ PMSF and $1 \mathrm{mM}$ EDTA. After addition of SDS up to $2.0 \%$, total proteins were extracted, followed by SDS-PAGE analysis. The protein extraction using SDS solution alone resulted in low concentration of proteins, showing about $0.05 \mathrm{mg} / \mathrm{mL}$ from $S$. cerevisise 30008. And the extents of protein from other two strains were also low (detailed data not shown).

The extraction of proteins was also tested with $\mathrm{NaOH}$ (up to 0.3 $\mathrm{N})$ alone for the three yeast strains by the same way. By this extraction, scarce contents of proteins were also released from each yeast strain, showing below $0.03 \mathrm{mg} / \mathrm{mL}$ (detailed data not shown). This insufficient release of proteins by $\mathrm{NaOH}$ is similar to the previous experiment (Kushnirov, 2000), which was performed with $S$. cerevisiae $5 \mathrm{~V}-\mathrm{H} 19$. However, when $\mathrm{NaOH}$ is used in combination with SDS for the three yeast cells in our experiment, the extents of protein release much increased and were roughly proportional up to $0.1-0.15 \mathrm{~N}$ of $\mathrm{NaOH}$ or $1.0 \%$ SDS (detailed data not shown). Therefore, final extraction of protein from the yeast cells was performed with complex solution consisted of $0.1 \mathrm{~N} \mathrm{NaOH}$ and $1.0 \%$ SDS.

Contrary to our result, it was shown that $0.3 \mathrm{M} \mathrm{NaOH}$ alone greatly improved the extraction efficiency of proteins from yeast (Matsuo et al., 2006). In this experiment, a fission yeast, Schizosaccharomyces pombe, was used, of which the cell wall carries additive cell wall components such as galactomannan (Ishiguro et al., 1998). This demand of higher alkaline solution for the protein extraction appears to be related with a difference in the cell wall composition between the fission yeast and another yeast cells such as Saccharomyces.

Protein extraction using ammonium hydroxide pre-treatment. Influence of pre-treatment with $\mathrm{NH} 4 \mathrm{OH}$ on the total protein extraction was examined for the three yeast strains. And the same experiment with $\mathrm{NaOH}$ was also simultaneously performed in order to compare the effect of pre-treatment between $\mathrm{NH} 4 \mathrm{OH}$ and
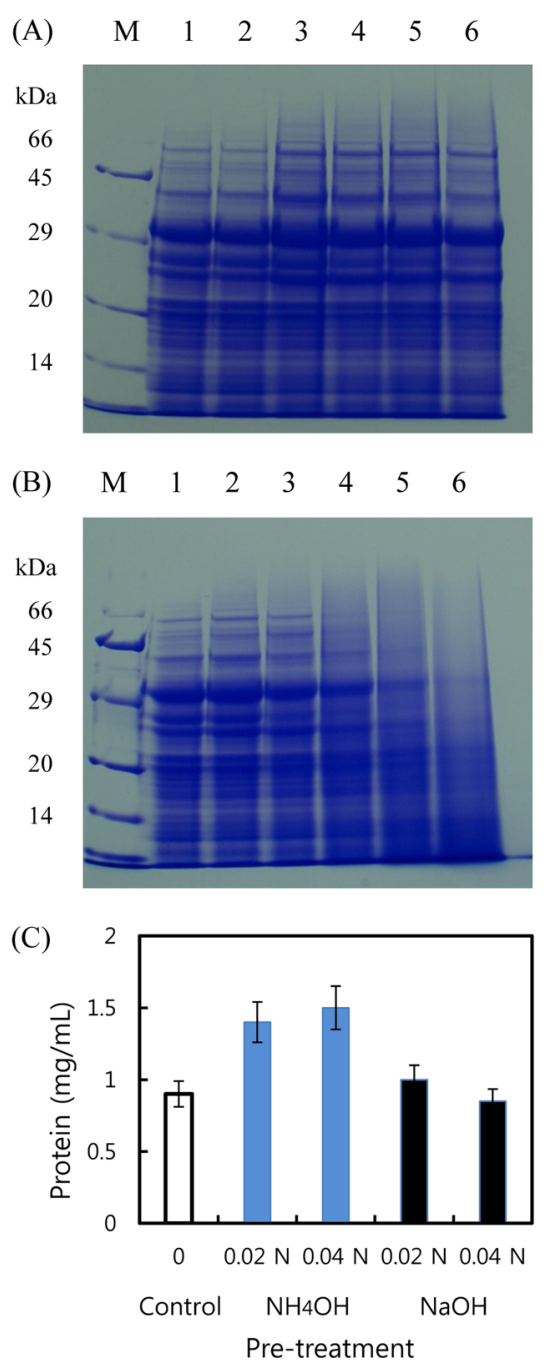

Fig. 1 Protein extraction from S. cerecvisiae (KACC 30008), which was pre-treated with $\mathrm{NH} 4 \mathrm{OH}$ (A) or $\mathrm{NaOH}$ (B) and measurements of protein content $(\mathrm{C})$. Proteins were extracted as described in materials and methods. Fig. (A): M, molecular mass markers; lane 1, no pre-treatment (control); lane 2-6 represent the pre-treatment of $\mathrm{NH} 4 \mathrm{OH} 0.02,0.04$, $0.06,0.08$ and $0.15 \mathrm{~N}$, respectively. Fig. (B): lane $\mathrm{M}$ and 1 are same as the Fig. (A); lanes 2-6 represent the pre-treatment of $\mathrm{NaOH} 0.02,0.04$, $0.06,0.08$ and $0.15 \mathrm{~N}$, respectively. Protein concentrations were measured at the pre-treatment of 0.02 and $0.04 \mathrm{~N} \mathrm{NH} 4 \mathrm{OH}$ or $\mathrm{NaOH}$.

$\mathrm{NaOH}$. For this experiment, the yeast cells were grown up to stationary phase. The resultant pellets were pre-treated up to 0.15 $\mathrm{N}$ of $\mathrm{NH} 4 \mathrm{OH}$ or $\mathrm{NaOH}$ and finally the total proteins were extracted using $0.1 \mathrm{~N} \mathrm{NaOH}$ and $1.0 \%$ SDS as described in materials and methods. The efficiencies of protein extraction were assessed by SDS-PAGE analysis and also by quantification of total proteins released (Fig. 1, 2 and 3). For the comparisons of effects between $\mathrm{NH} 4 \mathrm{OH}$ and $\mathrm{NaOH}$, the data were compared at the concentrations of 0.02 and $0.04 \mathrm{~N}$ treatment. Fig. $1-\mathrm{a}, \mathrm{b}$ and c show the protein extractions from S. cerevisiae KACC 3008, which were pre-treated with $\mathrm{NH} 4 \mathrm{OH}$ or $\mathrm{NaOH}$. When the yeast cells was pre-treated with $\mathrm{NH} 4 \mathrm{OH}$, the content of protein 

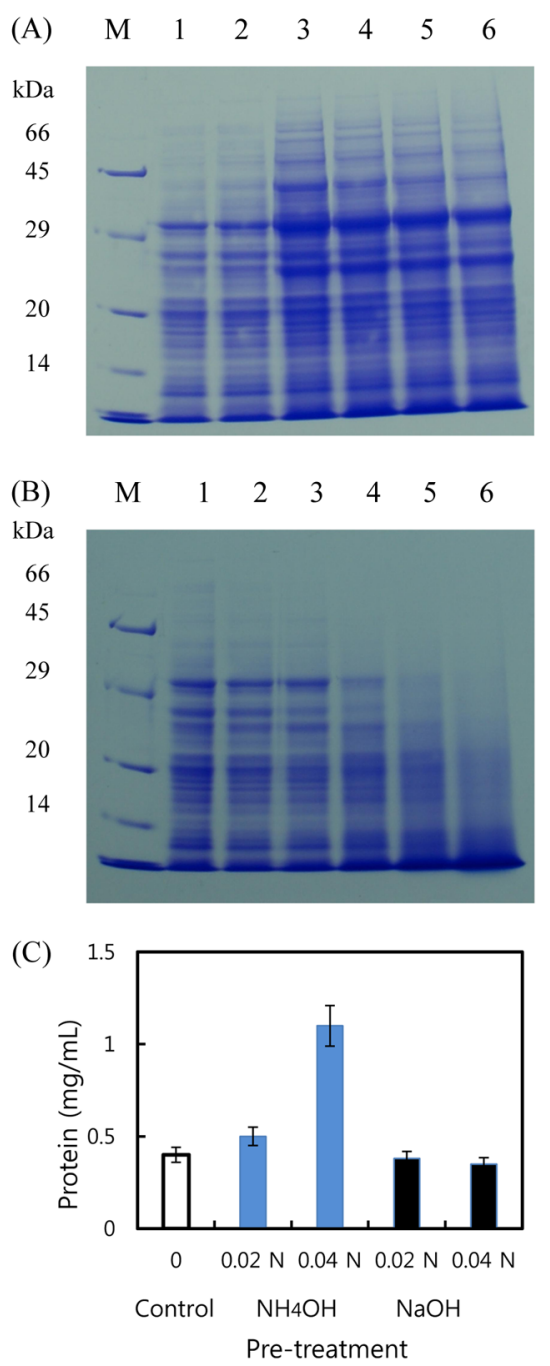

Fig. 2 Protein extraction from S. cerecvisiae (KACC 30044), which was pre-treated with $\mathrm{NH} 4 \mathrm{OH}(\mathrm{A})$ or $\mathrm{NaOH}(\mathrm{B})$ and measurements of protein content $(\mathrm{C})$. Proteins were extracted as described in materials and methods. Fig. (A): M, molecular mass markers; lane 1, no pre-treatment (control); lane 2-6 represent the pre-treatment of $\mathrm{NH} 4 \mathrm{OH} 0.02,0.04$, $0.06,0.08$ and $0.15 \mathrm{~N}$, respectively. Fig. (B): lane $\mathrm{M}$ and 1 are same as the Fig. (A); lanes 2-6 represent the pre-treatment of $\mathrm{NaOH} 0.02,0.04$, $0.06,0.08$ and $0.15 \mathrm{~N}$, respectively. Protein concentrations were measured at the pre-treatment of 0.02 and $0.04 \mathrm{~N} \mathrm{NH} 4 \mathrm{OH}$ or $\mathrm{NaOH}$.

extraction considerably increased (Fig. 1A). Under the basis of SDS-PAGE analysis, the optimum concentration of $\mathrm{NH} 4 \mathrm{OH}$ for the pre-treatment is observed around $0.04 \mathrm{~N}$. By the pre-treatment at this concentration, the final amount of protein increased by $67 \%$ compared with the control (Fig. 1C). It is notable that proteins with higher molecular weights were more extracted by the pretreatment with $\mathrm{NH} 4 \mathrm{OH}$. Figure 1-b shows the protein extraction from the yeast cell, which was pre-treated with $\mathrm{NaOH}$. Pretreatment of $\mathrm{NaOH}$ did not seem to further enhance the efficiency of protein extraction. By the pre-treatment of $0.02 \mathrm{~N} \mathrm{NaOH}$, only $11 \%$ of proteins increased compared with the control (without pretreatment) (Fig. 1C). About over $0.06 \mathrm{~N}$ of pre-treatment with
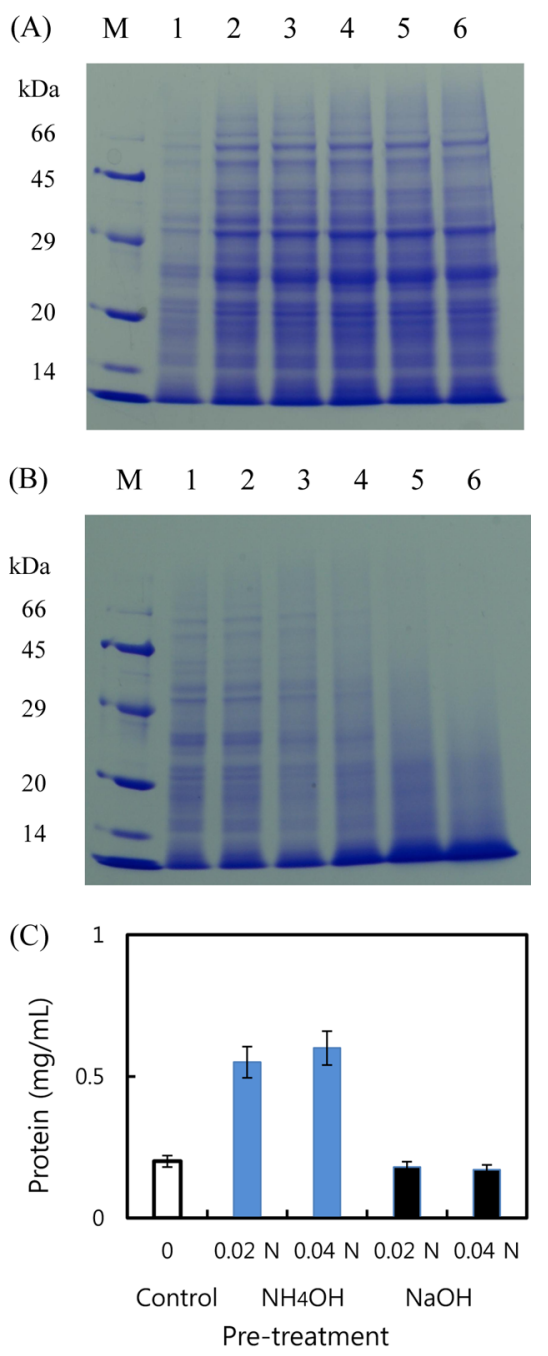

Fig. 3 Protein extraction from P. pastoris $\mathrm{x}-33$, which was pretreated with $\mathrm{NH} 4 \mathrm{OH}$ (A) or $\mathrm{NaOH}$ (B) and measurements of protein content (C). Proteins were extracted as described in materials and methods. Fig. (A): M, molecular mass markers; lane 1, no pre-treatment (control); lane 2-6 represent the pre-treatment of $\mathrm{NH} 4 \mathrm{OH} 0.02,0.04,0.06,0.08$ and $0.15 \mathrm{~N}$, respectively. Fig. (B): lane $\mathrm{M}$ and 1 are same as the Fig. (A); lanes 2-6 represent the pre-treatment of $\mathrm{NaOH} 0.02,0.04,0.06,0.08$ and $0.15 \mathrm{~N}$, respectively. Protein concentrations were measured at the pre-treatment of 0.02 and $0.04 \mathrm{~N} \mathrm{NH} 4 \mathrm{OH}$ or $\mathrm{NaOH}$.

$\mathrm{NaOH}$, total proteins appear to be rather decreased, when it compares with the control. The gradual decreases in protein content seem to be resulted from the precipitation of proteins at higher alkaline solution, since $\mathrm{NaOH}$ also exist in the final extraction buffer. Despite the decrease in protein content, smaller proteins, about below $15 \mathrm{kDa}$, occurred more at higher alkaline condition.

Pre-treatment with $\mathrm{NH} 4 \mathrm{OH}$ or $\mathrm{NaOH}$ for another yeast strain, $S$. cerevisiae KACC 30044, showed similar results with that of $S$. cerevisiae KACC 30008 . When the pre-treatment was performed with $\mathrm{NH} 4 \mathrm{OH}$, the total amount of protein drastically increased (Fig. 2A). The optimum concentration of $\mathrm{NH} 4 \mathrm{OH}$ was observed 


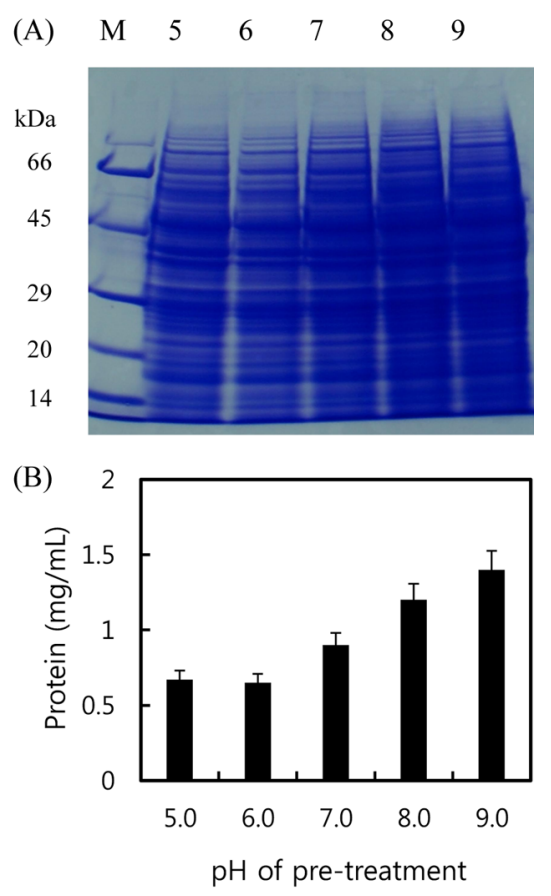

Fig. 4 Protein extraction from S. cerevisiae (KACC 30008), which was pre-treated with $\mathrm{NH} 4 \mathrm{OH}$ at different $\mathrm{pH}$ values (A) and its quantification of protein concentration (B). After the pre-treatment, proteins were extracted as described in materials and methods. Lane M, molecular mass markers; lane 5-9 represent the $\mathrm{pH}$ values of pre-treatment, each corresponding to $5,6,7,8$, and 9 of $\mathrm{pH}$, respectively. Protein concentrations were calculated from each corresponding sample of Fig. (A) and represented as the amount equivalent to BSA.

around $0.04 \mathrm{~N}$ based upon SDS-PAGE analysis, showing a similarity to the experiment with $S$. cerevisiae KACC 30008 . The amount of protein extraction increased by $175 \%$ of the control at the pre-treatment of $0.04 \mathrm{~N} \mathrm{NH} 4 \mathrm{OH}$ (Fig. 2C). Similar to the experiment with the strain $S$. cerevisiae KACC 30008 , it is notable that proteins with higher molecular weights were also more appeared from the strain 30044 on the SDS-PAGE by the pretreatment with $\mathrm{NH} 4 \mathrm{OH}$. The pre-treatment of $\mathrm{NaOH}$ did not further enhance the protein extraction, too (Fig. 2B). The protein content rather decreased even with the pre-treatment of low concentration of $\mathrm{NaOH}, 0.02 \mathrm{~N}$ (Fig. 2C). In this experiment, smaller proteins were also gradually appeared on the SDS-PAGE along with the increase in the concentration of $\mathrm{NaOH}$.

In addition to Saccharomyces strains, an effect of pre-treatment using $\mathrm{NH} 4 \mathrm{OH}$ or $\mathrm{NaOH}$ was also studied with P. pastoris (Fig. $3 \mathrm{~A}, \mathrm{~B}$, and C) by the same way. Similar to the Saccharomyces strains, the extraction of proteins from the Pichia strain was markedly enhanced by the pre-treatment of $\mathrm{NH} 4 \mathrm{OH}$ (Fig. 3A). By the pre-treatment of $0.04 \mathrm{~N} \mathrm{NH} 4 \mathrm{OH}$, about 3 fold of proteins were finally extracted (Fig. 3C). However, pre-treatment of $\mathrm{NaOH}$ did not further contribute to the enhancement of protein extraction, too (Fig. 3B).

Pre-treatment of ammonium hydroxide at different $\mathbf{p H}$ values. In general, ammonia reacts with water molecule at low $\mathrm{pH}$
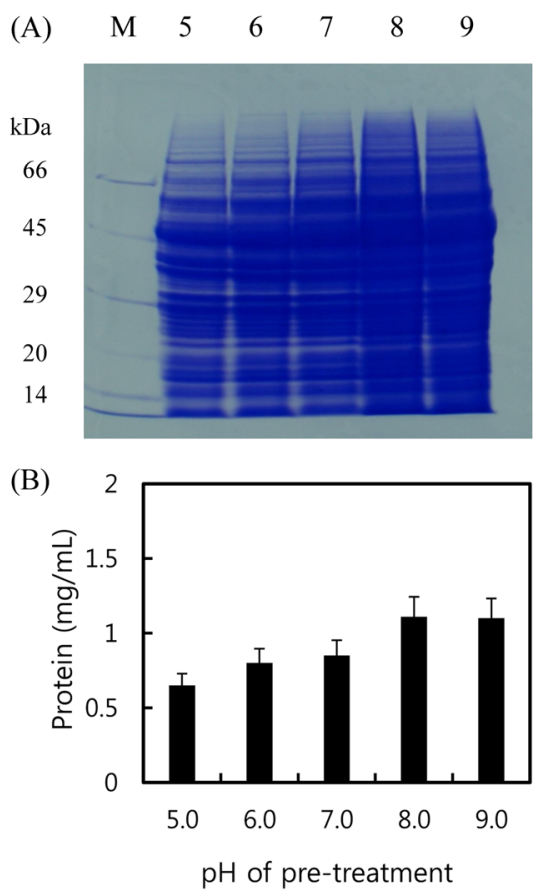

Fig. 5 Protein extraction from S. cerevisiae (KACC 30044), which was pre-treated with $\mathrm{NH} 4 \mathrm{OH}$ at different $\mathrm{pH}$ values (A) and its quantification of protein concentration (B). After the pre-treatment, proteins were extracted as described in materials and methods. Lane M, molecular mass markers; lane 5-9 represent the $\mathrm{pH}$ values of pre-treatment, each corresponding to $5,6,7,8$, and 9 of $\mathrm{pH}$, respectively. Protein concentrations were calculated from each corresponding sample of Fig. (A) and represented as the amount equivalent to BSA.

values, thus generating an ammonium $\left(\mathrm{NH}^{+}\right)$and hydroxide ion $\left(\mathrm{OH}^{-}\right)$. Above 9.0 of $\mathrm{pH}$, un-ionized ammonia is more predominant and un-ionized ammonia (NH3) can penetrate cell membranes more facilly at higher $\mathrm{pH}$ values (Stumm and Morgan, 1981). In this regard, an effect of $\mathrm{pH}$ on the ammonium pre-treatment was performed with the three yeast cells. The pre-treatment experiments were conducted with $0.04 \mathrm{~N}$ of $\mathrm{NH} 4 \mathrm{OH}$ solution at different $\mathrm{pH}$ values ranging from 5.0 to 9.0 of $\mathrm{pH}$ values. The suspension of yeast cells were incubated for $4 \mathrm{~h}$ with slow inversion agitation. After incubation, the suspension of yeast cells were centrifuged and supernatant discarded. The yeast cells were resuspended with Tris/HCl (pH 9.0, 0.1 M), supplemented with $1 \mathrm{mM} \mathrm{PMSF}$ and $0.2 \mathrm{mM}$ EDTA. Therefore, at the moment of final extraction, the suspensions of yeast cells retain the same $\mathrm{pH}$ condition, each other. The proteins of yeast cells were extracted with $0.1 \mathrm{~N} \mathrm{NaOH}$ and $1.0 \%$ SDS as described. The liberated proteins were assessed by SDS-PAGE analysis and the protein contents measured (Fig. 4, 5 , and 6). The amount of proteins extracted from $S$. cereviaise KACC 30008 was more enhanced from the pre-treatment at alkaline $\mathrm{pH}$ than neutral or weak acidic $\mathrm{pH}$ values (Fig. 4A). The protein content after the pre-treatment at $\mathrm{pH} 9.0$ increased by $56 \%$ compared with that by the pre-treatment at neutral $\mathrm{pH}$ of 7.0 (Fig. 4B), showing a strong dependency of $\mathrm{pH}$ values. The similar $\mathrm{pH}$ dependency of $\mathrm{NH} 4 \mathrm{OH}$ pre-treatment was also observed from the 


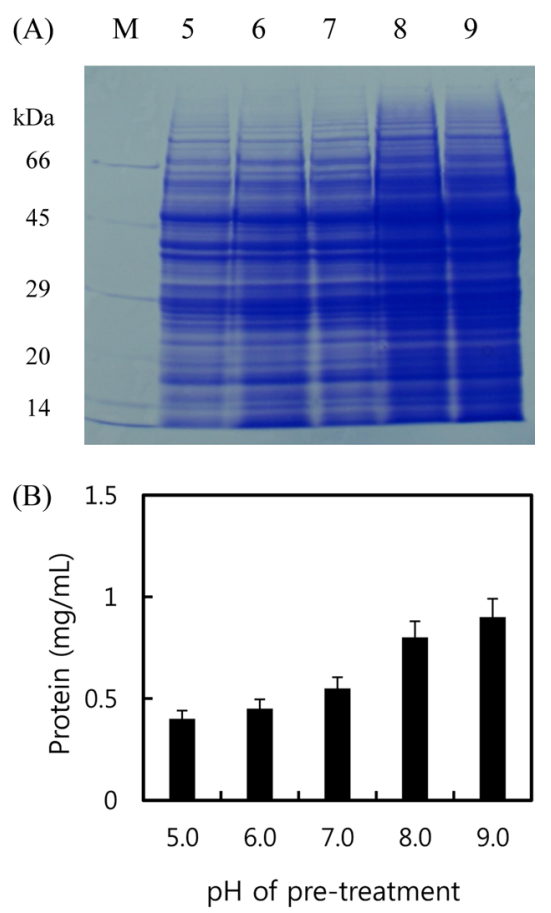

Fig. 6 Protein extraction from P. pastoris $\mathrm{x}-33$, which was pre-treated with $\mathrm{NH} 4 \mathrm{OH}$ at different $\mathrm{pH}$ values (A) and its quantification of protein extracted (B). After the pre-treatment of $\mathrm{NH} 4 \mathrm{OH}$ at different $\mathrm{pH}$ values, proteins were extracted as described in materials and methods. Lane M, molecular mass markers; lane 5-9 represent the $\mathrm{pH}$ values of pretreatment, each corresponding to $5,6,7,8$, and 9 of $\mathrm{pH}$, respectively. Protein concentrations were calculated from each corresponding sample of Fig. (A) and represented as the amount equivalent to BSA.

experiment for another strain S. cerevisiae KACC 30044 or Pichia (Fig. 5 and 6). At pH 9.0, the total proteins extracted from $S$. cereviaise KACC 30044 or P. pastoris increased by 25 , and $82 \%$, compared with each pre-treatment at neutral $\mathrm{pH}$, respectively (Fig $5 \mathrm{~A}$, Fig 6B). At neutral or weak acidic $\mathrm{pH}$ of pre-treatment, protein liberation was not considerably obtained.

Protein extraction using ammonium hydroxide alone. We tested whether a treatment of $\mathrm{NH} 4 \mathrm{OH}$ alone (without $\mathrm{NaOH}$ and SDS) can liberate proteins from the three yeast strains. For this experiment, $\mathrm{NH} 4 \mathrm{OH}$ was added up to $0.2 \mathrm{~N}$ to the yeast cells suspended with Tris/HCl buffer $(\mathrm{pH} 9.0,0.1 \mathrm{M})$, supplemented with $1 \mathrm{mM}$ PMSF and $0.2 \mathrm{mM}$ EDTA. The yeast suspensions were incubated for 1 or $8 \mathrm{~h}$ with gentle agitation using a vertical turntable. Then the solution of yeast cells were obtained by centrifugation. The resultant supernatants were analyzed by SDSPAGE and compared with the control (without treatment). The proteins released from the three yeast cells were scarce, resulting in below $0.05 \mathrm{mg} / \mathrm{mL}$ for three yeast strains. The amounts of proteins extracted were scarce regardless of the concentration and incubation time of $\mathrm{NH} 4 \mathrm{OH}$ (detailed data not shown). In combination with the results obtained from the above Figs 1, 2, and 3, it appears that $\mathrm{NH} 4 \mathrm{OH}$ itself does not significantly disrupt yeast cells and might merely contribute to weaken the structure of yeast cell walls, thus facilitating the subsequent protein extraction using detergent at alkaline $\mathrm{pH}$.

\section{Discussion}

The walls of yeast cells can withstand herculean pressure of $>300$ MPa (Hartman and Delgado, 2004), implying very tight structure of cell wall. Similar to Saccharomyces strains, cell walls of Pichia strains are also very strong. By reason of the complexity and strong structure of yeast cells, development of cell disruption or mechanical properties of Saccharomyces cell itself has been studied until recent years (Stowers and Boczko, 2007; Steson et al., 2011). There are some reports which deals with protein extraction from Saccharomyces cells using alkali solutions (Mrsa and Tanner, 1999; Kushnirov, 2000; Matsuo et al., 2006; Zhang et al., 2011). In these experiments, $\mathrm{NaOH}$ was used for the extraction of yeast proteins. Recently it was reported that protein extraction from $S$. cerevisiae can be ameliorated by combined use of lithium acetate and $\mathrm{NaOH}$ (Zhang et al., 2011). In this experiment, these reagents were pre-treated in order to enhance the permeability of yeast cells prior to protein extraction. For Pichia strains, a method of cell permeabilization using $\mathrm{N}, \mathrm{N}$-dimethyltetradecylamine was developed (Shapard et al., 2002). This method was proved to be more efficient than high-pressure homogenization.

Despite of some reports on the protein extraction from Saccharomyces strains, the extraction from Pichia strains has been insufficiently studied up to date. Furthermore, Pichia strains are widely used for extensive research works as a model of eukaryotic organism as well as Saccharomyces strains. Therefore we developed a protein extraction with two Saccharomyces strains and also with $P$. pastoris. We tried a pre-treatment of yeast cells prior to protein extraction in an attempt to test the possible weakening of cell wall and the resultant facility of protein extraction. For this experiment, $\mathrm{NH} 4 \mathrm{OH}$ solution was added into the suspension of yeast cells as a pre-treatment step. This pretreatment is a distinguishing method in our study, which differs from other method of protein extraction. By this pre-treatment, the final extraction of proteins drastically increased from $S$. cereviaise strains and $P$. pastoris X-33.

It was notable that the optimum condition of protein extraction from $P$. pastoris using the pre-treatment with $\mathrm{NH} 4 \mathrm{OH}$ was much similar to those of two yeast strains, $S$. cerevisiae KACC 30008 and KACC 30044. The pre-treatment with $\mathrm{NH} 4 \mathrm{OH}$ itself dose not appear to considerably disrupt the yeast cell walls under the basis that many of proteins, especially cytosolic proteins, should be readily liberated upon severe disruption of cell wall. But in this experiment, only low contents of proteins were released by the treatment of $\mathrm{NH} 4 \mathrm{OH}$ alone (data not shown). Therefore, the pretreatment with $\mathrm{NH} 4 \mathrm{OH}$ might mainly contribute to weaken the cell walls of yeast strains, thus making the cells more susceptible to the next step of protein extraction. In general, biological activities of many proteins are lowered during the extraction procedure, especially, under alkaline solution and/or detergent. 
The mechanims of ammonium hydroxide was not clearly elucidated in this paper. But based upon the report of Fujita et al., (2007), it is worthwhile to suggest that ammonium ion might weaken the hydrophobic interactions in the yeast cell wall or interior structure. For the proteomic analysis, enzyme activities are not important and sufficient extraction of protein is more important. In this regard, the methods developed in this experiment might be appropriate for the biochemical studies, especially proteomic analysis.

Collectively, the protein extractions using the pre-treatment with $\mathrm{NH} 4 \mathrm{OH}$ were much effective from two Saccharomyces strains and one Pichia strain. The method developed in this experiment is not the best method of extracting whole proteins from yeast cells. It would be hopeful if our method is applicable in combination with other methods of extraction through mutual supplementation of advantage and disadvantage, each other.

Acknowledgments This study was performed with the support of "Research program for Agricultural Science and Technology Development (Project No. PJ0086492012)". National Academy of Agricultural Science, Rural Development Administration, Republic of Korea.

\section{References}

Aita GA, Salvi DA, and Walker MS (2010) Enzyme hydrolysis and ethanol fermentation of dilute ammonia pretreated energy cane. Bioresour Technol 102, 4444-8.

Beukes N, Brett I, and Pletschke BI (2011) Effect of alkaline pre-treatment on enzyme synergy for efficient hemicelluloses hydrolysis in sugarcane bagasse. Bioresour Technol 102, 5207-13.

Bradford MM (1976) A rapid sensitive method for the quantitation of microgram quantities of protein utilizing the principle of protein dye binding. Anal Biochem 72, 248-54.

Conzelmann A, Riezman H, Desponds C, and Bron C (1988) A major 125 $\mathrm{kD}$ membrane glycoprotein of Saccharomyces cerevisiae is attached to the lipid bilayer through an inositol-containing phospholipid. EMBO J 7, 2233-40.
Fujita T, Watanabe H, and Tanaka S (2007) Effects of salt addition on strength and dynamics of hydrophobic interactions. Chem Phys Lett 434, 42-8.

Hartman C and Delgado A (2004) Numerical simulation of the mechanics of a yeast cell under high hydrostatic pressure. J Biomech 37, 977-87.

Horwath A and Riezman H (1994) Rapid protein extraction from Saccharomyces cerevisiae. Yeast 10, 1305-10.

Huang GL, Liu MX, and Mei XY (2005) Studies on the hydrolytic condition of $B-1,3$ glucan from yeast by fluorophore-assisted carbohydrate electrophoresis. Anal Lett 38, 477-85.

Ishiguro J (1998) Genetic control of fission yeast cell wall synthesis: the genes involved in wall biogenesis and their interactions in Schizosaccharomyces pombe. Genes Genet Syst 73, 181-4.

Karki B, Maurer D, and Jung S (2011) Efficiency of pretreatments for optimal enzymatic saccharification of soybean fiber Bioresour Technol 102, 6522-8.

Klis FM, Boorsma A, and De Groot PJ (2006) Cell wall construction in Saccharomyces cerevisiae. Yeast 23, 185-202.

Kushnirov VV (2000) Rapid and reliable protein extraction from yeast. Yeast 16, 857-60.

Kwasiborski A, Baji M, Delaplace P, Jardin P, and Jijakli H (2012) Biocontrol proteomics; development of an in situ interaction model and a protein extraction method for a proteomic study of the inhibiting mechanisms of Pichia anomala against Botrytis cenerea. Biocontrol 57, 1-12.

Laemmli UK (1970) Cleavage of structural proteins during the assembly of the head of bacteriophage T4. Nature 227, 680-5.

Matsuo Y, Asakawa K, Toda T, and Katayama S (2006) A rapid method for protein extraction from fission yeast. Biosci Biotechnol Biochem 70(8), $1992-4$.

Mrsa V and Tanner W (1999) Role of $\mathrm{NaOH}$-extractable cell wall proteins Ccw50, Ccw6p, Ccw7p and Ccw8p (members of the Pir protein family) in stability of the Saccharomyces cerevisiae cell wall. Yeast 15, 813-20.

Singh MR, Sandip R, and Bellare JR (2009) Influence of cryogenic grinding on release of protein and DNA from Saccharomyces cerevisiae. Int $J$ Food Eng 5, 1556-61.

Stowers CC and Boczko EM (2007) Reliable cell disruption in yeast. Yeast 24, 533-41.

Stumm W and Morgan JJ (1981) Aquatic chemistry. An introduction emphasizing chemical

equilibria in natural waters. A wiley Interscience publication, New York, USA.

Zhang TT, Lei J, Yang HJ, Xu K, Wang R, and Zhang ZY (2011) An improved method for whole protein extraction from Yeast Saccharomyces cerevisiae. Yeast 28(11), 795-8. 